\title{
Religious Freedom in the Perspective of Human Rights
}

\author{
Basuni $^{1}$, Azis Budianto ${ }^{2}$ \\ University Of Borobudur ${ }^{1,2}$ \\ \{basuniunboro@gmail.com ${ }^{1}$, azis_budianto@borobudur.ac.id $\left.{ }^{2}\right\}$
}

\begin{abstract}
Freedom of religion needs to be protected by the state, so that the enforcement of human rights can be sensed by the community, especially in the implementation of religious management in Indonesia. By using normative juridical methods and qualitative approaches, it is found that the State guarantees freedom of religion and belief for all people as stated in the applicable laws, as the protection of human rights for all people. The state guarantees freedom of religion and belief for all people as stated in the prevailing laws, as the protection of human rights for all people.
\end{abstract}

Keywords: Religious Freedom; Human Rights; Legal Protection

\section{Introduction}

Indonesia is a country consisting of various ethnic groups and cultures. These various tribes occupy various existing islands. With a total of 17,504 islands, of course, the various ethnic groups and communities have a lot of diversity, from culture to religion.[1] This diversity gives a different color to Indonesia compared to other countries. Apart from the area which is in the form of islands and also the various tribes in it. The diversity that exists also exists in the social life of the community.

This diversity is the identity of Indonesia. Besides, this is also an opening for problems. The most problem that can emerge is conflict amid differences and diversity. Differences become a problem when not everyone can accept the diversity that exists in their environment.[2] Some conflicts arise over diversity. Religious conflict is one of the conflicts that occur in Indonesia's diversity. A case involving religious issues by former DKI Governor, Basuki Tjahja Purnama, involved two camps, both supporters and opposing sides. The GKI Yasmin church polemic, the forced cessation of worship places, as well as pamphlets in the name of a certain regional head wherein the pamphlets, were written Christians should not celebrate Christmas in that area. These various cases prove that there is a diversity gap involving religious issues emerging in Indonesia, whether exposed by official national media or news circulating on social media. Apart from cases between religious communities, problems within one religion also occur. For example, in Solo city, when a Muslim religious leader held a celebration event, the event was forcibly disbanded by another Muslim mass organization until the religious leader was injured. Apart from that, insults against one of the Muslim religious leaders by fellow Muslim religious leaders also occurred. Later, the case was thought to have occurred because of the issue of radical understanding in certain religions where this understanding also leads to acts of terrorist activity. 
Recently, the issue of terrorism, related to religious radicalism has become one of the things that deserve attention in Indonesia. Radical religious acts that lead to terror are nothing new for Indonesia [3]. History records radicalism, not only religion that occurred in Indonesia, which was equivalent to rebellion and separatist efforts to break Indonesian unity, for example, the PKI in Madiun, DI / TII in West Java, and Aceh. At that time Indonesia was able to face the conflict, but the problem is whether Indonesia can face these problems today. Extreme acts tend to cause casualties and damage, even if they are linked to religious ideas. This act of radicalism can be appropriate as a terrorist act. Of course, these acts of terror and other extreme actions threaten Indonesia's national security. The Indonesian police have taken several measures to prevent and deal with these cases, but as stated by Zamrani, it is like the tip of the iceberg phenomenon, when the Republic of Indonesia police created an anti-terror department, they were able to catch some terrorists but the main brain of the real terrorists and masterminds; accused of being the main organization behind all the bombings in Indonesia, still cannot reveal. Meanwhile, for some other extreme actions such as burning churches, cafes, and police bars, they can only remain in place without doing anything. Attacks against minority groups, such as the Christian minority in Temanggung, Ahmadiyah in many parts of Indonesia, and other minority groups were caused by government hesitation which led to an aperture of policies to prevent extreme religious acts. [4] Governments tend to seem like they want to please everyone, but everyone has their satisfaction, so that is why it is difficult to achieve satisfaction for everyone. For example, a survey result presented by Kurniawan wrote that some sections and Muslim organizations in Indonesia agree that state law changes with sharia; they are the Islamic Defenders Front and the Indonesian Mujahidin Council, on the other hand, the two largest organizations Nahdatul Ulama and Muhammadiyah accept pluralism and support the existing law. [5] This shows that not all groups are the majority; in this case, Muslims, have the same opinion and perception about a perspective in society.

To be able to create harmony in society, practical steps that can be taken are needed. One of the steps that can be taken is religious moderation. An order of life and understanding that accepts other religions or beliefs. [6] Thus, each party can accept the existence of the other without abandoning each other. This religious moderation behavior will be able to foster unity in society to avoid division. Acceptance of the existence of another group will trigger socialpsychological well-being.[7]

A moderate lifestyle will lead to tolerance. Acceptance of diversity will build people's awareness to tolerate. Strong tolerance in society will keep society from being divided. Even with that would avoid radical ideologies. This is because, with the acceptance of diversity, a religious adherent will not consider that his religion is the truest and accept the differences that exist.[8] This diversity is also a blessing from the Almighty to be preserved for the sake of Indonesian unity. An attitude of tolerance is an entry point for respecting human rights in the field of belief and religion. Besides being guaranteed by the 1945 Constitution, freedom of religion is also a human right in choosing and determining one's belief.[9] This paper will discuss the human rights perspective on religious freedom in society.

\section{Method}

This study uses a normative juridical method with a qualitative approach,[10] by collecting and utilizing information related to the problems in this study. This research nature is descriptive analysis, namely research that describes and analyzes how religious freedom is 
part of human rights, in this case where the role of the state is concerned in protecting these human rights.

\section{Discussion}

Since what is in the system is man himself, religion in the community system plays an important role in the social system of society.[11] Thus religion and society are two things that are interrelated and cannot be separated. Within a diverse community system likely to arising conflict. Conflict is something that always attracts attention to be examined in human life. Thus, community life cannot be separated from the existence of conflict. Furthermore, Wyn stated that mental health counseling plays a major role in conflicts over pluralism, where the existence of appropriate counseling will lead to positive psychology in society.[12] Positive psychology in society is proven to be able to build resilience for peace in society.

Religious moderation is the acceptance of other beliefs apart from the beliefs held by a person. The journey of religious moderation in Indonesia has been going on since the early history of Indonesian independence, at which time diversity had begun to exist.[13] However, even though moderation has been going on since 1999, violence against other beliefs still occurs. This pluralism and diversity can be intertwined when there is acceptance of that diversity. This acceptance will create harmony.

From time to time, the life of human civilization has experienced many developments. One of the things that were born from the process of human civilization is the understanding and understanding of human rights (HAM). In the context of human rights, the state is the main legal subject, because the state is the main entity responsible for protecting, upholding, and advancing human rights. In human rights law, rights holders are individuals, while the duty bearer in the state. The state has three generic obligations related to human rights, namely obligation to respect, the obligation to protect, and the obligation to fulfill. On the other hand, individuals are bound by the obligation not to interfere with the human rights of other individuals.[14]

The state's obligation to respect human rights will be violated if the state takes action (commission) against something which should be passive or refrain from enjoying the rights that will be carried out by individuals. For example, in terms of the right to freedom of religion or belief. The constitution and various laws and regulations in Indonesia have insured the right to freedom of religion or belief. However, at present, the condition of the guarantee of the right to freedom of religion or belief in Indonesia is increasingly concerning. Various reports from year to year shows that violations of the right to freedom of religion or belief continue to increase. Several problems related to violations of the right to freedom of religion or belief (not merely the problem of increasing intolerance that causes violations) continue to occur, but in some cases, state officials both at the national and local levels are involved or even support these violations. Coupled with the existence of various regulations that violate the right to freedom of religion or belief, including the emergence of new regulations that are not in line with human rights principles. In this case, the state has committed an offense by taking action (commission) which precisely limits and violates the right to freedom of religion or belief. [15] Various human rights in various aspects of life can be explained as follow:

a. Political rights, namely the right to participate in government, the right to vote and be elected in elections, the right to establish a party, etc.

b. Property right (Economic), the right to own something, buy and sell it, and use it. 
c. Right of legal equality, namely the right to receive equal treatment in law and government. As well as the right to receive equal treatment in judicial procedures and protection (procedural right). For example, regulations in arrest, search, trial, etc.

d. Social and cultural rights, for example, the right to choose education, develop culture, etc.

e. Personal right, which includes freedom of expression, freedom to embrace religion, etc.

The above discriminatory acts constitute human rights violations, both vertical (committed by state officials against citizens or vice versa) or horizontal (between citizens themselves); and not a few are included in the category of gross violations of human rights.

Actions or actions that interfere with the religious freedom of a person or group of people are acts that constitute a violation of human rights. It is declared in Law Number 39 of 1999 concerning Human Rights, Chapter 1 Article 1 point 6 which is written "Violation of human rights is every act of a person or group of people including state officials, whether intentional or unintentional or negligent, limiting, and/or revoke the human rights of a person or group of people guaranteed by this law, and do not receive, or are worried that they will not obtain a fair and correct legal settlement, based on the applicable legal mechanism. " Therefore, the state or government through its apparatus should not ignore any events related to intolerance events that have occurred.

Of course, to build safe and peaceful conditions in carrying out religious activities, it cannot be separated from the participation of the community. The community has an important role to play in building conditions of security and peace. The community is also expected to know human rights in religion and practice worship. Actions that lead to things related to disturbing religious activities (intolerance) are certain things that violate human rights. The community is expected to be sensitive to acts of intolerance and dare to oppose these events. Either by going directly and taking action to prevent the incident from continuing, or immediately reporting to the relevant government agencies/institutions. Human civilization will certainly be more useful if it is filled with peace, which will increase prosperity.

The existence of Law Number 39 of 1999 concerning Human Rights is a barometer of the government's ability to organize a nation-state wheel based on human rights. Still in Law Number 39 of 1999 concerning Human Rights, the section considering letter d is written, "that the Indonesian nation as a member of the United Nations has the moral and legal responsibility to uphold and implement the Universal Declaration of Human Rights. stipulated by the United Nations, as well as various other international instruments regarding human rights that have been accepted by the Republic of Indonesia". Some of these things are another form of seriousness from the Indonesian government, that human rights are present in the life of the nation and state in Indonesia. However, it will not be sufficient to reach the regulatory level without concrete implementation in the field.

The concept of a rule of law is a state based on the rule of law. Punish the sovereign. The state is a legal subject, in the sense of rechtstaat (republic legal entity). Because the state is seen as a legal subject, then if he is guilty, he can be prosecuted in front of a court for violating the law. Finally, all provisions made by the government must be based on law. There is no such thing as a policy based on power. In the description above it can be concluded as the relationship between human rights and the rule of law. In upholding human rights, it must be based on legal rules, namely statutory regulations. The government, in sustaining human rights in a law-based country, must continually pay attention to the applicable regulations.

State protection for the community, especially in terms of religious freedom, needs to be implemented in terms of protecting human rights. Freedom of religion needs to be protected 
by the state, so that the enforcement of human rights can be felt by the community, especially in the implementation of religious management in Indonesia. The comfort of the community in embracing their religion is an important priority in upholding the law so that human rights can be implemented properly at the level of social practice. The state guarantees freedom of religion and belief for all people as stated in the prevailing laws, as the protection of human rights for the entire community.

\section{Conclusion}

Religious freedom is part of human rights. It has been declared in Law Number 39 of 1999 concerning Human Rights Article 22 paragraph (1) which states, "Everyone is free to embrace their respective religions and to worship according to their religion and belief". Then paragraph (2) is written, "The state guarantees the freedom of everyone to embrace his religion and belief". In the future, the government through related government apparatus/agencies such as the Ministry of Religion and the Ministry of Home Affairs together with National Commission of Human Rights need to disseminate information to all law enforcement officials and local government officials to know and understand that religious freedom is part of human rights. Law enforcement officials and local governments are obliged to maintain religious freedom in living as a nation and state in Indonesia. Policies or regulations that are born, must be based on human rights. Must not conflict with the law above.

\section{Reference}

[1] Central Bureau Statistic, Several Main Indicator Development of Indonesian SocioEconomiy. 2019.

[2] F. J. Nugroho, "Mystical Rituals: Studies on Ritual of Ngalab Berkah on Mount Kemukus," Hanifiya J. Stud. Religions, vol. 3, no. 1, pp. 14-26, Jun. 2020, doi: 10.15575/hanifiya.v3i1.8431.

[3] M. I. Zamrani, "Islam, Islamic Boarding Schools and Terorism," J. Educator. Islam, vol. 2, no. 2, pp. 177-194, 2005.

[4] B. Hasan and A. Mursalin, "Communal Conflict in the Name of Religion in Indonesia: Analysis of the Ahmadiyah Conflict in Media Coverage, 2005-2011.," Context. J. Researcher. Sos. Religious, vol. 26, no. 1, pp. 90-115, 2011.

[5] Kurniawan, "Formalization Dynamics of Islamic Sharia in Indonesia," Kanun J. Law Science., vol. 14, no. 3, pp. 423-447, 2012, doi: https://doi.org/10.24815/kanun.v14i3.6223.

[6] Y. D. Indraswari, "Encouraging Meeting to Care for Diversity." PPIM UIN Jakarta., Jakarta, 2019.

[7] A. M. Brewer, "Mentoring from a Positive Psychology Perspective. In Mentoring from a Positive Psychology Perspective." Springer International Publishing, 2016, doi: https://doi.org/10.1007/978-3-319-40983-2.

[8] F. J. Nugroho, S. Octavianus, Y. R. Yuono, and D. N. Sari, "RELIGIOUS SERVICE PARADIGM IN MANAGING THEOLOGICAL SEMINARY Email : Fibryjatinugroho@gmail.com,”Sinergi, vol. 9, no. 2,pp. 1-5, 2019.

[9] Romli Atmasasmitha, "International Criminal Law and the Law of Human Rights," 2005. 
[10] I. M. P. Diantha, "Normative Legal Research Methodology," Theor. Methodol. Researcher. a., 2017.

[11] F. J. Nugroho, Reconstruction of Post-Conflict Rituals in the Religious Tourism Object of Mount Kemukus, Sragen Regency, Central Java. Salatiga: Faculty of Theology SWCU, 2017.

[12] F. J. Nugroho, "Holistic Pastoral Assitance: A Conceptual Proposal for Development of Church Citizens," Evang. J. Teol. Evangelical dan Pembin. Congregation, vol. 1, no. 2, pp. 139-154, 2017.

[13] Z. A. Bagir, A. G. A. Dwipayana, M. Rahayu, T. Sutanto, and F. Wajidi, Citizenship Pluralism: A New Direction of Politic Diversity in Indonesia. Bandung: Mizan Pustaka, 2011.

[14] E. Hidayat, "Protection of Human Rights in the State of Law of Indonesia," Principles of J. Law. and Econ. Islam, vol. 8, no. 2, pp. 80-87, 2016, [Online]. Available: https:/www.neliti.com/publications/56534/perlindungan-hak-asasi-manusia-dalamnegara-hukum-indonesia.

[15] S. M. Mulia, "Human Rights and Freedom of Religion 1," 2007. 